\title{
True Vivipary in two Remarkable Pinguicula (Lentibulariaceae) FROM THE CARIBBEAN, P. LIGNICOLA AND P. CASABITOANA
}

\author{
Paul TeMPle $・$ Santo Domingo $・$ Dominican Republic • paulindr@gmail.com \\ IVAN PANCO $\bullet$ London $\bullet$ United Kingdom \\ Cristina M. Panfet Valdéz • Jardin Botanico Nacional de Cuba • Ciudad de La Habana • Cuba \\ Colmar A. Serra - Instituto Dominicano de Investigaciones Agropecuarias y Forestales (IDIAF) \\ - Ecotopía E.I.R.L. • Santo Domingo • Dominican Republic • Pontificia Universidad Católica \\ Madre y Maestra $\bullet$ CSTA • Depto. de Ecología y Gestión Ambienta • Santo Domingo • Dominican \\ Republic
}

Keywords: Pinguicula lignicola, Pinguicula casabitoana, Lentibulariaceae, carnivorous plant, Caribbean, Dominican Republic, Cuba, epiphyte, true vivipary, cryptocotylar germination.

Abstract: Pinguicula lignicola had been described as "viviparous" but no evidence had ever been presented, nor clarification given, as to the type of vivipary displayed. Early reports of young plants or stalked-seeds present within the bell-shaped calyx (with the implication that the capsule has opened) implied that false vivipary might be occurring, later tentatively considered in our early but superficial observations. We extended those observations to conduct more detailed investigations of $P$. lignicola and P. casabitoana, previously described as very similar. Our study demonstrated new similarities. In particular, we provide detailed evidence to confirm that both species exhibit true vivipary, the diaspores of these two species being seedlings, not seeds. In addition, we present evidence that the seeds undergo cryptocotylar germination, the first occasion on which this has been reported in Pinguicula. We also identify that fixation of a seedling to a phorophyte depends on its attachment by root hairs; these two Pinguicula do not exhibit roots before or during fixation, by the time the cotyledons have fully emerged, or before the first eophyll emerges.

\section{Introduction}

Within the genus Pinguicula (Lentibulariaceae), P. lignicola Barnhart, of Cuba, and P. casabitoana Jiménez, of the Dominican Republic, are both epiphytes, an unusual characteristic among the Carnivorous Plants (Givnish et al. 2017), to which these two species belong. Both are endemics that, as deduced from a study of Peruvian flora (Ibisch et al.1996), is unusual because "epiphytes excepting some genera of Orchidaceae, do not show high values of endemism" (Hechavarría Schwesinger \& Oviedo Prieto 2002). Casper (2019) identified 16 species (with one comprising 2 sub-species) from the Greater Antilles. Considering only the species, Schlauer (2019) clarified and reduced this to 14 . In contrast to the rich diversity in Cuba, in the Dominican Republic P. casabitoana is the only known representative of its genus.

It has been stated that "worldwide, Pinguicula species share similar breeding system and reproductive patterns" (Molano-Flores et al. 2018) but we now present evidence that $P$. lignicola and $P$. casabitoana are remarkable exceptions.

Since details of Pinguicula casabitoana were first published (Jiménez Almonte 1960), it had been obvious that both this species and P. lignicola shared the characteristic of being obligate epiphytes. Yet ca. 30 years passed before indication of the close similarity of both species was 
summarized with the succinct comment, "P. casabitoana may be conspecific with P. lignicola" (Casper 1987). Thereafter, both species escaped significant attention and so remained largely unobserved and generally uninvestigated. This relative obscurity was interrupted by our undertaking this work, which arose as a result of field trips to Cuba in the 1990s (Temple 1995, 1997), during which Pinguicula species were observed in habitat, including P. lignicola.

During our first encounter with a wild colony of the species, we observed objects within the calyces. The earliest and brief mention of these objects, all in relation to Pinguicula lignicola, stated:

Im glockenförmigen Kelch öfter junge Pflänzchen. [In the bell-shaped calyx there are often young plants] (Ernst 1961: 175).

Ernst's observation was soon cited:

Ernst (1961) hat übrigens eine Art von Viviparie beobachtet: Im glockenförmigen Kelch fanden sich öfter junge Pflänzchen. [Ernst (1961), by the way, also observed a type of vivipary: young plants were often found in the bell-shaped calyx] (Casper 1966: 98).

Further, in reference to adaptation to epiphytism, the objects in the calyces were again mentioned, confusingly adding mention of long stems:

die Samen sind gering an Zahl und ziemlich lang gestielt [the seeds are few in number and quite long-stalked] (Casper 1966).

Two subsequent mentions confusingly failed to refer to "young plants" or "vivipary" while continuing reference to "long-stalked" or just "stalked" seeds:

In den Fruchtkelchen finden sich bis zu 35 langestielte Samen, die ohne Stiel zwischen 0,8 und 1,2 $\mathrm{mm}$ messen [In the fruiting calyces there are up to 35 long-stalked seeds that measure between 0.8 and $1.2 \mathrm{~mm}$ without including the stalk] (Bisse et al. 1975)

Stalked seeds and the existence of leaves of different sizes and forms resemble the Heterophyllum-Isolobopsis group. (Casper, 1987: 353)

Such historic mentions of "junge Pflänzchen [juvenile plantlets], "viviparie" [vivipary], "langestielte Samen" [long-stalked seeds] and "stalked seeds", were never accompanied by any illustration representing the objects in the calyx cup and neither was any explanation or text description offered to discuss those objects in any detail, leaving their identity as unclear and ambiguous.

Our immediate belief, during field observations of P. lignicola in Cuba, was that the objects in the calyces were very young viviparous plants developing from seed stalks (Temple 1997), but, for reasons both practical and personal, confirming the identity of the structures took ca. 20 years. A beneficial part of our expanded interest was the previously unreported observation that $P$. casabitoana shared the presence of remarkably similar (almost identical) objects within the calyces (Temple 2001). It was this discovery that simplified access to material such that more detailed observations could be made and the identity of the structures could be verified. 
All work was done with appropriate permission obtained from applicable authorities. In Cuba, this required ministerial and local permits for all participating botanists and, additionally, scientific visas for those who were non-nationals. In the Dominican Republic, verbal permission was required for visits to Loma del Casabito [Mount Casabito] while additional ministerial permission was necessary for the most recent studies that involved habitat access and specimen acquisition.

Live Pinguicula lignicola material (plants attached to phorophytes) was observed in habitat and both attached and detached capsules were observed using eye, loupe, and camera. Live $P$. casabitoana material was observed in habitat (plants attached to phorophytes) and capsule and whole plant specimens were returned to the laboratory of the Jardin Botanico Nacional [National Botanic Garden] in Santo Domingo where observations of the fresh, unpreserved material were made using a camera, microscope, and binocular microscope with integral camera.

\section{Observations}

Entire capsules (fruits), representing different stages of maturity, were examined and contained as many as ca. 50, translucent, green, seeds in P. casabitoana (Figs. 1, 2), though as few as 13 in P. lignicola.

In immature capsules (Fig. 1), these were fusiform-ellipsoid (pear-shaped). Laboratory examination revealed that when seeds were removed from the capsules, they would desiccate rapidly, well within one hour. Dissected mature capsules revealed the seeds to be more elongated or cylindroid (Fig. 2).

Our observations confirm that these seeds do not

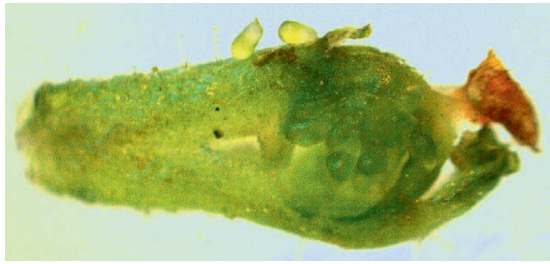

Figure 1: A sealed Pinguicula casabitoana capsule (all but one sepal removed) with seeds within. Two individual fusiform-ellipsoid seeds (top) were from a separate capsule. Photo: Paul Temple.

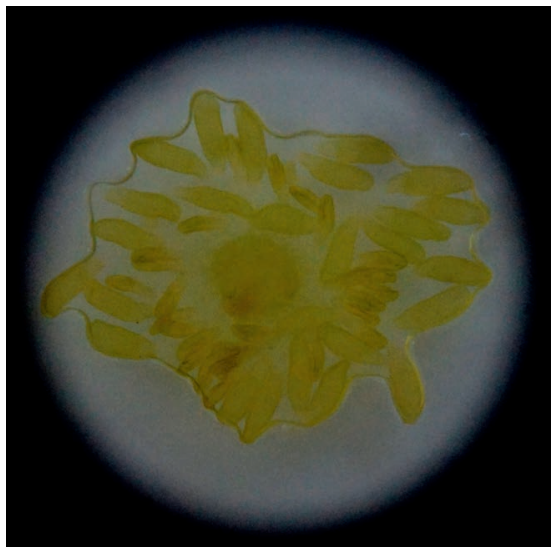

Figure 2: A dissected capsule of Pinguicula casabitoana revealing ca. 50 seeds plus the round placenta at center. Photo: C. Serra. undergo dormancy. Following fertilization, the seeds in the capsule grow continuously, both in width and length (Figs. $1,2)$.

In plants whose capsules had opened, the cup-shaped calyces held the elongated cylindrical, seeds, and also what were obviously seedlings at varying stages of further development. This included that they had become broader, longer, slightly curved, tapered cylindroids (Fig. 3). At

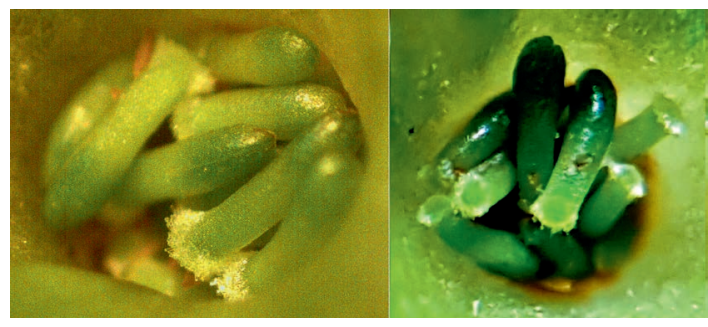

Figure 3: Very similar seedlings within the calyces of Pinguicula casabitoana (left) and P. lignicola (right). Photo: Paul Temple (left) \& Ivan Panco (right). 


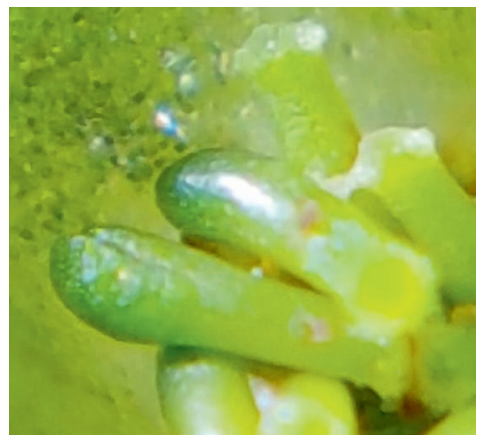

Figure 4: Pinguicula lignicola seedlings in the calyx, on the left showing very early indication of separation of the cotyledons. Photo: Ivan Panco.

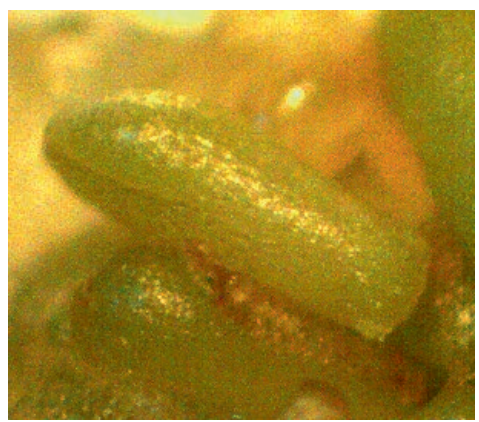

Figure 5: Immature seedling of Pinguicula casabitoana from inside the calyx, early indication of separation of the cotyledons. Photo: Paul Temple.

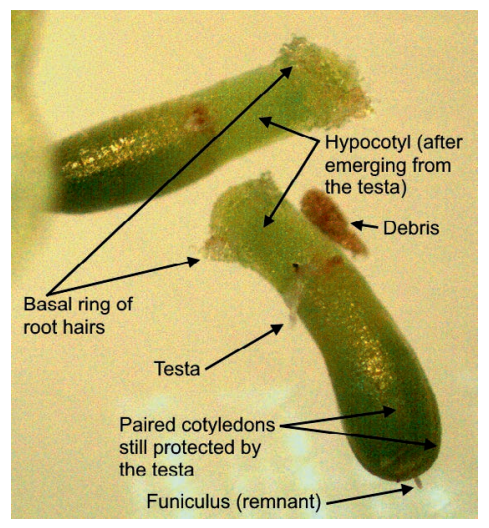

Figure 6: Pinguicula casabitoana capsule objects showing typical seedling features. Photo: Paul Temple. first observed (superficially) by us in $P$. lignicola, these objects were later observed, in detail, including in P. casabitoana.

These seedlings were by far the most intriguing characteristic of both obligate epiphytic species. Bisse et al. and Casper's earlier descriptions of "langgestielte Samen" [long-stalked seeds] (also referred to in English by Casper) in the calyx led to the initial but incorrect hypothesis that the objects observed represented seed stalks developing into plantlets (P. Temple, personal communication, January 30, 2013, 17:40). If occurring, such a process would have constituted an example of false vivipary.

Within the calyces, many of the cylindroid seedlings (Figs. 3-6) bore root hairs that, in contrast, were absent from the pear-shaped or more mature cylindroid seeds (Figs. 1-2) within the closed capsules. Cotyledons were observed to begin the early stage of separation while seedlings were held in the calyx.

Following fertilization, the seeds in the capsule grew both in width and length (Figs. 1, 2). By 6 weeks, the seeds had changed size and shape to become tapering cylindroids and emerged from the capsule into the calyx cup (Fig. 3), where they quickly acquire characteristics (Fig. 6) to eventually include: a basal ring of root hairs positioned at the distal end; an emerged hypocotyl that has burst through the testa; two not yet distinctly separated cotyledons still within and protected by the testa; and the funiculus remnant that (observed at higher magnification but not reproduced herein), is confirmed to be as was first described by Ernst (1961: 175), "unregelmäßig tordierten Stielen [irregularly twisted stems]". Hence, this is a case of true vivipary, the structures dispersed by these two species being seedlings (germination and development occurring inside the calyx) rather than seeds.

In laboratory cultivation, some seedlings demonstrated obvious signs of the beginnings of cotyledon separation while still in the calyx but, in the wild, this was either less common or proceeded to a lesser developmental stage. In the wild, cotyledons usually, if not always, demonstrated separation (Fig. 7) after seedling dispersal; their expansion added to the size of the seedlings such that there was no longer space for them within the calyx. Note the remnant of the opened seed coat (testa) still adhering, like a hat, to one of each cotyledon pair for each seedling in Fig. 7. The seed coat envelope illustrates the growth of the seedling that happened after germination began - the testa marks the size and shape of the fully developed seeds, as the seed coat does not enlarge or grow with the seedling. All seedling 
growth happened after the seedling's hypocotyl burst through the testa.

Dispersal occurred when the peduncle began to decompose (P. Temple, personal communication, January 21, 2013; Lampard et al. 2016), though other mechanisms also contribute to dispersal (to be published in a future article).

Twin cotyledons ("seed leaves"), seen here with an emerging first eophyll ("true leaf"; Fig. 8), fully emerge and separate after dispersal and are succulent and very sparsely glandular. They last very briefly and are rarely observed as the eophylls emerge very quickly to replace them. The eophylls, obovate with rounded ends, are amply glandular and efficient at trapping small insect prey (Fig. 9), except at their transparent margins that are without glands.

\section{Discussion}

Viviparous germination of seeds within the calyx is evidenced in Pinguicula lignicola and P. casabitoa$n a$ by the emergence of the hypocotyl from the testa. (The possibility of earlier germination within the capsule cannot be entirely discounted but was never observed.) The cotyledons remain within the seed coat that, as noted by Dr. A. Fleischmann (personal communication, January 14, 2020), demonstrates cryptocotylar germination. This is the first occasion on which this has been reported for the genus Pinguicula. The term, cryptocotylar, was first coined to describe plant cotyledons "remaining in the testa after germination" (Duke 1965).

Although seedlings held within the calyx sometimes show a greater degree of development of the cotyledons in laboratory cultivation than do plants in the wild, development is not more rapid in the laboratory; the seedlings generally remain undispersed for longer than happens in the wild, allowing more time for the cotyledons to begin separating.

The viviparous development of seedlings, followed by their rapid growth while they are retained within the calyx and, thereafter, also quickly followed by dispersal, allows no time during which seeds can become dormant and the need for fixation to a phorophyte obviates the need for or possibility of seed dormancy.

As the reproductive process observed in Pinguicula lignicola and P. casabitoana is the same, the same type of vivipary (four types distinguished sensu Elmquist \& Cox 1996) will apply to both species. Pseudovivipary (false vivipary), an asexual process, cannot apply because the observed pro- 
cess in the two Pinguicula is sexual, beginning with seeds in the capsule. Induced pseudovivipary cannot apply because, for all specimens seen, all plants undergoing reproduction demonstrated only that same process; for a process induced by a fungal infection, some plants would not be infected (see Clay 1986; Dubey et al. 2011). Cryptovivipary (semi-vivipary) cannot apply because all seeds did leave the capsule and undergo significant further development before dispersal. Hence it is a case of true vivipary, where the embryo grows to a considerable size outside of the capsule before dispersal; the diaspores, in this case seedlings rather than seeds, pass their developmental stages, from seed germination to seedling maturity, while within the calyx, not within the capsule. Definitions of dispersal usually refer to seed (rather than seedling) and are not pertinent to P. lignicola and $P$. casabitoana. A general definition of dispersal that includes relevance to seedlings is: "any movement of individuals or propagules with potential consequences for gene flow across space" (Ronce 2007).

The work by Ernst (1961) requires some additional comment. It remains unclear why Ernst provided no details or illustrations of the plantlets he was first to observe in the calyx cups of Pinguicula lignicola. He also omitted mention of root hairs that we explain as most likely to be the result of him having examined seedlings after seeds are released from the capsule, also after the development of the hypocotyl that gives an extended appearance to what are then seedlings, but while they are still sufficiently immature to lack any root hairs. In addition, Ernst described the attachment of seeds as "lange mit der Plazenta verbunden [attached to the placenta for a long time]". It is quite evident that in viviparous species, the developing seedling remains attached to the placenta, to be nourished by the mother plant via the funiculus (as is also true for seed developing in the ovary). This period will be extended until the seedlings are ready for dispersal.

Work by Bisse et al. (1975) also requires comment. They reported what they considered to be long-stalked seeds in the calyx measuring "zwischen 0,8 und 1,2 $\mathrm{mm}$ [between 0.8 and $1.2 \mathrm{~mm}$ ]". This corresponds in size to the viviparous seedlings that we observed when sufficiently developed to exhibit a basal ring of root hairs (Figs. 10, 11). We cannot definitively explain, for the larger objects seen and interpreted as seeds by Bisse et al., why root hairs might have been entirely absent or why mention of them would have been omitted. A possibility is that the material observed was preserved and the root hairs reduced or absent as a result of damage by dehydration.

Nevertheless, based on our current knowledge of both Pinguicula lignicola and P. casabitoana, there is no evidence in

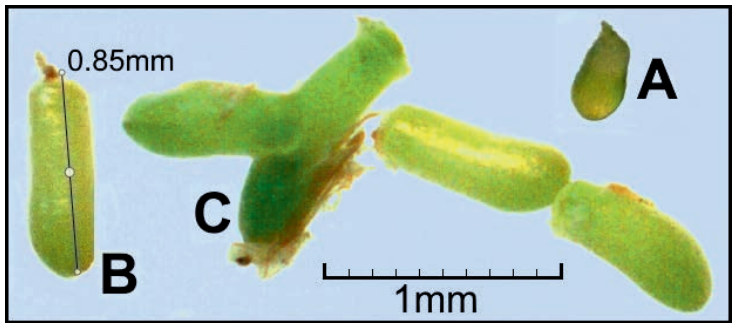

Figure 10: Pinguicula casabitoana seed and seedlings showing form and size: A) seed; B) immature seedling; C) mature seedling with basal ring of root hairs. Photo: Paul Temple.

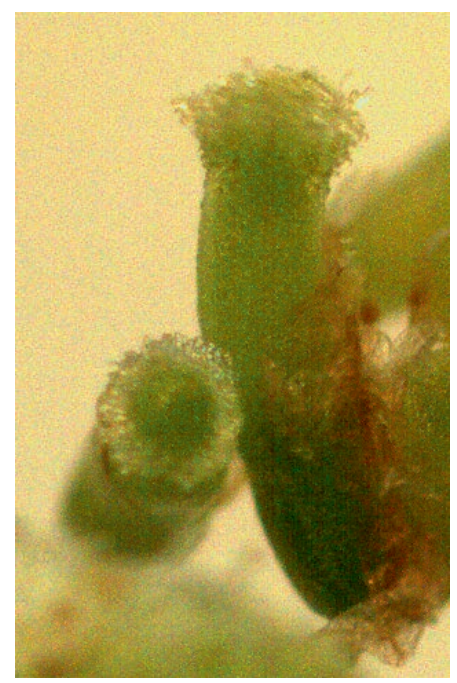

Figure 11: Pinguicula casabitoana seedlings with basal rings of root hairs. Photo: Paul Temple. 
earlier literature that conflicts with our proposal that both species exhibit true vivipary. As further evidence, the development of seeds in the capsule, their germination into seedlings in the calyx, and their development of cotyledons followed by the emergence of eophylls, has now been observed by us in cultivation (Figs. 7, 8). This is the first occasion on which definitive evidence of true vivipary in these two species, obtained either in habitat or in cultivation, has been formally published, though it was preceded by an audio-visual symposium presentation, at El XIV Congreso Internacional de Investigación Cientifica [the XIV International Congress of Scientific Research], Santo Domingo, Dominican Republic (P. Temple, S. Colmar, Y. Marte, \& M. Galán, personal presentation, June 7, 2018). This is remarkable, not just because it is the first such report of true vivipary in the genus but also because true vivipary is very uncommon in flowering plants (Farnsworth 2000; Cota-Sánchez 2004; Leck \& Outred 2008) and most "prevalent among plants in tropical shallow marine habitats, either in Mangrove or in sea grass communities" (Elmqvist \& Cox 1996). Even the broader category of general vivipary is "a rare reproductive strategy in flowering plants" (Cota-Sanchez 2004), described for "143 genera and 195 species spanning 80 vascular plant families" (Bhadra et al. 2013) with many of the examples representing pseudovivipary.

True vivipary in Pinguicula lignicola and P. casabitoana conforms to van der Pijl's (1982) conclusion, that vivipary is an adaptation to a wide range of environments, based on abolition of protection, desiccation and a rest period. Both species live in micro-habitats characterized by permanent high humidity with frequent and reliable wetting (by clouds and rain), an environment that facilitates true vivipary by obviating the requirement for seeds to become dormant while insufficient water is available for growth. Accommodated by a suitable environment, it seems these two species have evolved their method of true vivipary as an adaptation to their habit as obligate epiphytes; true vivipary is not found in any other species of Pinguicula, including species that grow in similarly wet and humid habitats, even in those few that can be found growing epiphytically. Vivipary provides an effective solution for an obligate epiphytic species to have its offspring become established; for $P$. lignicola and $P$. casabitoana, establishment is effected with propagules that develop sufficiently to have a ring of basal root hairs as a means of gaining a foothold on a phorophyte, the surface of which may often be made wet or buffeted by wind and rain. The $360^{\circ}$ unbroken ring of root hairs guarantees that, when the lower end of a seedling is in contact with a phorophyte, its orientation will not present a barrier to fixation; some root hairs will always be presented to the phorophyte. The root hairs provide the only means by which a seedling can fix to a phorophyte as roots do not emerge before or during fixation.

\section{Conclusions}

True vivipary is proposed for both Pinguicula lignicola and $P$. casabitoana as a result of confirmation of the presence of seedlings in the calyces and the clear evidence that they develop from sexual seeds in the capsule. These are the first two taxa to have been reported as exhibiting true vivipary in their genus.

We believe that true vivipary in these two species has evolved as a reproductive benefit. It is a strategy that copes with the need to ensure reproductive success despite available habitats being severely restricted in size (micro-habitats), widely distributed and inhospitable to seeds of obligate epiphytes that are generally unable to rapidly gain a secure purchase on surfaces that are damp and frequently exposed to heavy rain and strong wind.

If Pinguicula lignicola was deserving of being called "a botanical sensation" (Casper 1987) for the discovery that it was and remains a rare example of an epiphytic member of the Lentibulari- 
aceae, the first epiphyte to be known within its genus, to now confirm that it and the very closely related $P$. casabitoana each exhibit true vivipary specifically enabled by a unique reproductive solution must surely elevate both obligate epiphytic species to being literally exceptional and the most extraordinary of the Pinguicula.

Acknowledgements: We extend our grateful thanks to a number of institutions and people whose assistance made this work possible:

El Jardin Botanico Nacional de Cuba [The National Botanic Garden of Cuba] (in Havana) and, in particular, the late Director, Dra. Ángela Leiva Sánchez, for obtaining official permits for the expeditions including scientific visas for the non-Cuban botanists. Also, La Oficina de Regulación Ambiental del Ministerio de Ciencia Tecnología y Medioambiente [The Office of Environmental Regulation of the Ministry of Science Technology and Environment] for granting the permits.

El Ministerio de Medio Ambiente y Recursos Naturales [The Ministry of the Environment and Natural Resources] of the Dominican Republic (DR) and, in particular: Das. Ramon Emilio Castillo (Medio Ambiente) for local permissions for visits to Mt. Casabito; Sr. Ángel Estévez, for issuing full study permits; Sr. Adalberto Abreu del Orbe (Medio Ambiente) for assistance with the application for permission to study Pinguicula both in and removed from protected areas.

The Director Regional de Turismo de Constanza [Director of Tourism for Constanza, DR], Juan Marun Tactuk Concepción, for assisting Paul Temple gain access to the Reserva Cientifica Ebano Verde for his first visit in 1997.

El Jardin Botanico Nacional Dr. Rafael Ma. Moscoso [The Dr. Rafael Ma. Moscoso National Botanical Garden] of Santo Domingo (Dominican Republic) and, in particular: its Director, Dr. Ricardo Garcia, for giving permission to access resources, especially accession data and laboratory equipment; Yuley Encarnacion Piñeyro for arranging access to the binocular microscope.

Marcel van den Broek (Netherlands) for advice regarding part of our cultivation experimentation and for other general support. Dr. Vitor Miranda (Universidade Estadual Paulista), Dr. Andreas Fleischmann (Botanische Staatssammlung Munich), and Martin Reith (Hispaniola) for literature, information, and verification relating to Pinguicula morphology. Dr. Yoannis Dominguez (Universidade Estadual Paulista) for assistance in obtaining botanical literature. The anonymous peer reviewers for objectivity and knowledge.

\section{References}

Barbedo, C.J., Centeno, D. da C., and Ribeiro, R. de C.L.F. 2013. Do recalcitrant seeds really exist? Hoehnea 40(4): 583-593. https://dx.doi:.org/10.1590/S2236-89062013000400001

Bhadra, S., Ghosh, M., Mukherjee, A., and Bandyopadhyay, M. 2013. Vivipary in Hedychium elatum (Zingiberaceae). Phytotaxa 130(1): 55-59. 10.11646/phytotaxa.130.1.7

Bisse, J., Lippold, H., and Casper, S.J. 1975. Beiträge zur Kenntnis der westindischen PinguiculaArten. Wissenschaftliche Zeitschrift, Mathematisch-naturwissenschaftliche Reihe 24: 377-385.

Casper, S.J. 1966. Monographie der Gattung Pinguicula L. Biblioteca Botanica 127/128.

Casper, S.J. 1987. On Pinguicula lignicola, an epiphytic heterophyllic member of the Lentibulariaceae in Cuba. Plant Systematics and Evolution 155: 349-354.

Casper, S.J. 2019. The Insectivorous Genus Pinguicula (Lentibulariaceae) in the Greater Antilles. Botanic Garden and Botanical Museum, Berlin.

Clay, K. 1986. Induced vivipary in the sedge Cyperus virens and the transmission of the fungus Balansia cyperi (Clavicipitaceae). Canadian Journal of Botany 64(12): 2984-2988. https://doi:. org/10.1139/b86-394 
Clifford, H.T. 1991. Germination patterns in dicotyledons. Aliso 13(1): 207-213.

Cota-Sánchez, J.H. 2004. Vivipary in the Cactaceae: Its taxonomic occurrence and biological significance. Flora 199: 481-490. 10.1078/0367-2530-00175

Dubey, A., Gupta, S., and Singh, T. 2011. Induced vivipary in Sesamum indicum L. by seed borne infection of Phytophthora parasitica var. sesame. Indian Journal of Fundamental and Applied Life Sciences 1(2): 185-188. http://www.cibtech.org/jls.htm

Duke, J.A. 1965. Keys for the identification of seedlings of some prominent woody species in eight forest types in Puerto Rico. Annals of the Missouri Botanical Garden 52(3): 314-350. https:// www.jstor.org/stable/2394796?seq=1

Elmqvist, T., and Cox, P. 1996. The evolution of vivipary in flowering plants. Oikos 77(1): 3-9. $10.2307 / 3545579$

Ernst, A. 1961. Revision der Gattung Pinguicula. Botanische Jahrbücher für Systematik Pflanzengeschichte und Pflanzengeographie 80(2): 145-194.

Farnsworth, E. 2000. The ecology and physiology of viviparous and recalcitrant seeds. Annual Review of Ecology and Systematics 31: 107-138.

Givnish, T.J., Sparks, K.W., Hunter, S.J., and Pavlovič, A. 2017. Carnivorous epiphytes should be rare but myrmecophytic epiphytes should be more common. In: A. Ellison \& L. Adamec (eds.) Carnivorous Plants: Physiology, Ecology, and Evolution. Oxford University Press. pp 247-248.

Hechavarría Schwesinger, L., and Oviedo Prieto, R. 2002. Epiphytic angiosperms of Cuba. Selbyana 23(2): 224-224.

Ibisch, P., Boegner, A., Nieder, J., and Barthlott, W. 1996. How diverse are neotropical epiphytes?

An analysis based on the "Catalogue of the flowering plants and gymnosperms of Peru". Ecotropica 2: 13-28.

Jiménez Almonte, J. de J. 1960. Pinguicula casabitoana Jiménez, sp. nov. Rhodora 62: 238.

Lampard, S., Gluch, O., Robinson, A., Fleischmann, A., Temple, P., McPherson, S., and Legendre, L. 2016. Pinguicula of Latin America. Redfern Natural History Productions.

Leck, M.A., and Outred, H.A. 2008. Seedling natural history. In: M.A. Leck, V.T. Parker, \& R.L. Simpson (eds.). Seedling Ecology and Evolution. Cambridge University Press.

Molano-Flores, B., Primer, S., Annis, J., Feist, M.A., Coons, J., and Digges, R. 2018. Reproductive ecology of three rare North American Pinguicula species. Plant Species Biology 33(2): 129-139.

Ronce, O. 2007. How does it feel to be like a rolling stone? Ten questions about dispersal evolution. Annual Review of Ecology, Evolution, and Systematics 38: 231-253. 10.1146/annurev. ecolsys.38.091206.095611

Schlauer, J. 2019. The Pinguicula benedicta 'puzzle' resolved. Carnivorous Plant Newsletter 48(3): 121.

Temple, P. 1995. Cuba Field Trip. Retrieved November 07, 2018, from http://www.omnisterra.com/ botany/cp/list/cp95alld/1495.htm

Temple, P. 1997. Cuba Field Trip. Retrieved November 07, 2018, from http://www.omnisterra.com/ botany/cp/list/cp97all.d/2369.htm

Temple, P. 2001. George - a lament. Retrieved November 07, 2018, from http://www.pinguicula.org/ pages/culture/George.htm

Tomlinson, P.B. 1994. The Botany of Mangroves. Cambridge University Press.

van der Pijl, L. 1982. Principles of Dispersal in Higher Plants ( $3^{\text {rd }}$ and Revised Edition). SpringerVerlag. 